\title{
Boundary line approach applied among crop emergence parameters and soil physical properties
}

\author{
Osvaldo Guedes Filho' ${ }^{1}$, Alvaro P. Silva ${ }^{2}$, Neyde F. B. Giarola ${ }^{3}$, \\ Cássio A. Tormena ${ }^{4} \&$ Renata B. Mazzini-Guedes ${ }^{1}$ \\ ${ }^{1}$ Universidade Federal do Paraná. Jandaia do Sul, PR, Brasil. E-mail: osvaldoguedes@ufpr.br (Corresponding author) - ORCID: 0000-0001-8550-8505; \\ renataguedes@ufpr.br - ORCID: 0000-0003-2424-4862 \\ ${ }^{2}$ Universidade de São Paulo/Escola Superior de Agricultura “Luiz de Queiroz”. Piracicaba, SP, Brasil. E-mail: apisilva@usp.br - ORCID: 0000-0002-1544- \\ 7310 (In memorian) \\ ${ }^{3}$ Universidade Estadual de Ponta Grossa. Ponta Grossa, PR, Brasil. E-mail: neydegiarola@gmail.com - ORCID: 0000-0001-5240-9033 \\ ${ }^{4}$ Universidade Estadual de Maringá. Maringá, PR, Brasil. E-mail: catormena@uem.br - ORCID: 0000-0003-2351-9289
}

\begin{abstract}
The boundary line technique has been proposed for interpreting biological data where one variable is a biological response and the other is an independent variable. The objective of this study was to correlate maize and soybean emergence parameters with soil seedbed physical properties using a boundary line approach. The study was performed at the experimental farm belonging to the Universidade Estadual de Ponta Grossa, in the municipality of Ponta Grossa, Paraná State, Brazil. The area has been managed under a no-tillage system for 18 years. The emergence percentage (EP) and emergence rate (ER) were determined for maize and soybean crops. Soil seedbed physical properties were evaluated for both crop species and included soil penetration resistance, volumetric water content, aggregate stability, tensile strength, friability, saturated soil hydraulic conductivity, bulk density, and the least limiting water range. The boundary line approach was applied to pairs of values of plant emergence parameters and soil seedbed physical properties, and then the regression model was adjusted to the boundary points. The boundary line approach indicated that crop emergence was dependent on soil seedbed physical properties. It was possible to determine the optimum values of soil seedbed physical variables for crop emergence. The boundary line approach is a promising and complementary tool to better understand crop emergence responses to soil seedbed physical properties.
\end{abstract}

Key words: seeds, biological data, soil-plant relations

\section{Procedimento "boundary line" aplicado entre parâmetros de emergência de culturas e propriedades físicas do solo}

RESUMO: A técnica "boundary line" foi proposta para interpretar dados biológicos, onde uma variável é uma resposta biológica e a outra uma variável independente. O objetivo do trabalho foi correlacionar parâmetros de emergência de milho e soja com propriedades físicas da cama de semeadura do solo aplicando o procedimento "boundary line". O estudo foi conduzido na Fazenda Experimental da Universidade Estadual de Ponta Grossa, em Ponta Grossa, PR. A área é manejada sob sistema plantio direto há 18 anos. Foram determinados o índice de velocidade de emergência e a taxa de emergência para as culturas do milho e da soja. As propriedades físicas avaliadas na cama de semeadura de milho e soja foram: resistência do solo à penetração, conteúdo volumétrico de água, estabilidade dos agregados, resistência tênsil, friabilidade, condutividade hidráulica do solo saturado, densidade do solo e intervalo hídrico ótimo. O procedimento "boundary line" foi aplicado aos pares de valores dos parâmetros de emergência e propriedades físicas do solo, sendo em seguida ajustado um modelo de regressão para os "boundary" pontos. A aplicação do procedimento "boundary line" evidenciou que a emergência das culturas é dependente das propriedades físicas da cama de semeadura do solo. As relações obtidas permitiram conhecer os valores ótimos das propriedades físicas do solo para os parâmetros de emergência das culturas. O procedimento "boundary line" mostrou-se uma ferramenta promissora e complementar para melhor entender a resposta de emergência das culturas em relação às propriedades físicas da cama de semeadura do solo.

Palavras-chave: sementes, dados biológicos, relações solo-planta 


\section{INTRODUCTION}

The seedbed is one of the main requirements for plant growth, as its formation is essential to germination, seedling emergence, and crop establishment. The seedbed represents the physical soil environment created immediately after sowing, and its influence may vary greatly regarding soil aggregation and porosity (Atkinson et al., 2007).

In tillage systems where soil mobilization occurs, the seedbed results directly from soil preparation operations (Håkansson et al., 2002). In soil-conserving management systems, such as no-tillage, the seedbed originates only by the sowing operation, which promotes furrow openings for seed and fertilizer deposition because of the lack of soil turnover (Guedes Filho et al., 2013).

The soil preparation for seedbed formation directly influences soil temperature, water content, oxygen availability, and penetration resistance, which could all potentially affect seedbed performance and the ability to provide an appropriate environment for crop emergence (Atkinson et al., 2007).

Soil physical properties are the main determinants for seedling emergence and establishment. At this stage, nutrients are of secondary importance since seedlings still use seed reserves. However, one of the difficulties for researchers is how to correlate plant variables with soil ones. To address this issue, the boundary line approach has been used to demonstrate how soil properties influence plant biological parameters. The boundary line technique has often been proposed for the interpretation of biological data (Lewandowski \& Schimdt, 2006; Blanco-Macías et al., 2010; Matula, 2011; Topp et al., 2013; Maia \& Morais, 2016), where one variable is a biological response while the other variable is an independent one (Webb, 1972).

Webb (1972) suggested that, when working with dispersal graphs among dependent and independent variables, if the data set is large enough, the line connecting the points located at the outer margin represents the functional dependence of these variables; the independent variable on this line is the only limiting factor for the dependent variable. Points located below the upper edge (outer edge) denote the influence of either other independent variables or variable combinations that limit the dependent variable (Blanco-Macías et al., 2010). The boundary line is a trend line empirically adjusted to those points that form the outer line in the dispersion graph.

The objective of this work was to study relationships between variables of maize and soybean emergence with soil seedbed physical properties using the boundary line approach.

\section{Material ANd Methods}

The study was carried out at "Capão da Onça" experimental farm belonging to Universidade Estadual de Ponta Grossa (UEPG), located in the municipality of Ponta Grossa, Paraná State, Brazil ( $25^{\circ} 5^{\prime} 52^{\prime \prime} \mathrm{S}$ and $50^{\circ} 2^{\prime} 43^{\prime \prime} \mathrm{W}$, at $1,080 \mathrm{~m}$ of altitude). The soil was classified as a Rhodic Hapludox, with clay-sandy texture (EMBRAPA, 2013) and slopes varying from 3-8\%. The climate in the region, according to the Köppen classification, is humid subtropical mesothermal (Cfb), with an annual mean rainfall of $1,545 \mathrm{~mm}$ and an annual mean temperature of $18.7^{\circ} \mathrm{C}$.
The experimental area has been managed under a no-tillage system for 18 years. It has been under crop rotation with maize (Zea mays L.) and soybean (Glycine max L.) in Spring/Summer, and wheat (Triticum aestivum L.) and black oat (Avena strigosa Schreb) with vetch (Vicia sativa L.) consortium in Autumn/ Winter.

Variables of maize and soybean crop emergence were obtained by the number of emerged seedlings per meter counted from each selected point used for the collection of undisturbed soil samples. Maize and soybean were sown at the density of 5.6 and 18.0 seeds $\mathrm{m}^{-1}$, respectively. Plant emergence, which happened at seven and five days of sowing for maize and soybean, respectively, was evaluated daily up to when emergence stabilized, occurring at 12 and 11 days after sowing for maize and soybean, respectively. From plant emergence data (plants $\mathrm{m}^{-1}$ ), the emergence percentages (EP) (Eq. 1) and emergence rates (ER) (Eq. 2) were calculated as described by Maguire (1962):

$$
\begin{gathered}
\mathrm{EP}=\frac{\mathrm{N}_{\mathrm{F}}}{\mathrm{N}_{\mathrm{S}}} 100 \\
\mathrm{ER}=\frac{\mathrm{N}_{1}}{\mathrm{t}_{1}}+\frac{\mathrm{N}_{2}}{\mathrm{t}_{2}}+\ldots+\frac{\mathrm{N}_{\mathrm{n}}}{\mathrm{t}_{\mathrm{n}}}
\end{gathered}
$$

where:

$\mathrm{N}_{\mathrm{F}}$ - final number of emerged seedlings per meter;

$\mathrm{N}_{\mathrm{S}}$ - number of seeds sown per meter;

$\mathrm{N}_{1}, \mathrm{~N}_{2}$, and $\mathrm{N}_{\mathrm{n}}$ - numbers of emerged seedlings at the first, second and last counts; and,

$t_{1}, t_{2}$, and $t_{n}$ - numbers of days from sowing up to the first, second, and last counts, respectively.

The soil seedbed physical properties evaluated were penetration resistance, volumetric water content, bulk density, aggregate stability, aggregate tensile strength, friability, saturated hydraulic conductivity, and least limiting water range. Guedes Filho (2012) has described procedures for sampling and methodology used for determination of these soil physical properties.

The methodology used for the boundary line approach was proposed by Casanova et al. (1999) and adapted by VizcaynoSoto \& Cote (2004). First, data outliers were removed when their presence was detected. Second, independent variable data were divided into 10 equidistant classes, and then the highest value of the dependent variable for each class was selected. Consequently, all points of each class were represented by only one point. Therefore, these values indicate the boundary points. Vizcayno-Soto \& Cote (2004) suggested that, if necessary, outliers of boundary points could also be removed. However, when possible, a minimum of six points must always be used as recommended by Lewandowski \& Schmidt (2006). Finally, the most appropriate regression model for boundary points was adjusted. Different functions have been tested to describe the effect of the independent variable on the biological one: linear (Casanova et al., 2002), exponential (Lewandowski \& Schmidt, 2006), polynomial (Vizcayno-Soto \& Cote, 2004; Blanco-Macías 
et al., 2010), and S-shaped asymmetric (Imhoff et al., 2010; Otto et al., 2011). In this study, both linear and quadratic polynomial functions were adjusted using SAS software PROC REG and PROC NLIN (SAS Institute, 2002).

\section{Results AND Discussion}

In general, the dispersion graphs plotted among emergence parameters and soil physical properties showed a curvilinear format, except for penetration resistance and volumetric water content $(\theta)$. The emergence rate (ER) was related both strongly and negatively to both mean penetration resistance and $\theta$ values measured along the maize seedbed (Figures $1 \mathrm{~A}$ and $\mathrm{B}$ ). This indicates that maize ER decreased with penetration resistance and $\theta$ increase. Weaich et al. (1992), who also worked with maize and observed a decline in leaf elongation with the increase of penetration resistance, corroborate these results. Notably, there were very high $\theta$ values in the maize seedbed that ranged from $0.35-0.48 \mathrm{~m}^{3} \mathrm{~m}^{-3}$ for the boundary points. Therefore, the excessive soil moisture may impair crop speed emergence. Both penetration resistance and $\theta$ accounted for

A.

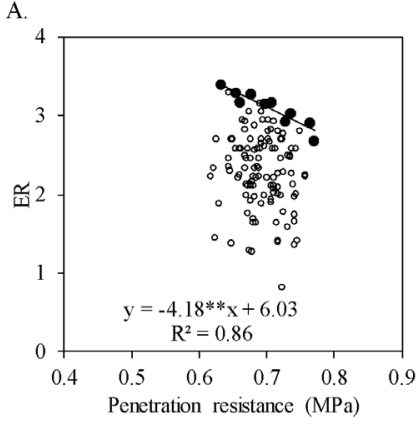

C.
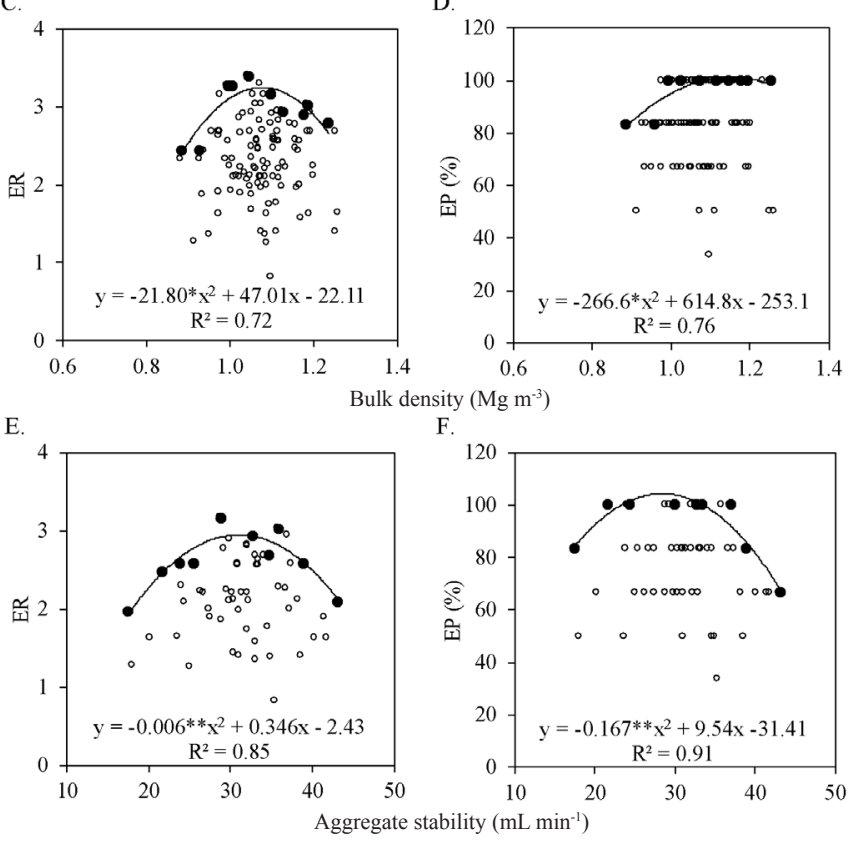

*, ** Significative at 0.05 and 0.01 , respectively, by F test

Figure 1. Dispersion and regression graphs from the boundary line approach for maize plant emergence [emergence rate (ER) and emergence percentage (EP)] and soil seedbed physical properties [(A) - penetration resistance; $(\mathrm{B})$ - volumetric water content $(\theta)$; (C) and (D) - bulk density; (E) and (F) - aggregate stability]
$86 \%$ of ER variability. Silva et al. (2004) found that only $43 \%$ of the variability in the height of maize plants was explained by the penetration resistance because of a negative relationship between those variables. For EP, there was no significant adjustment to the boundary points with penetration resistance and $\theta$ (data not shown).

The ER showed a strong initial increase with bulk density $(\mathrm{Bd})$ presenting a greater response among $\mathrm{Bd}$ values ranging from $0.88-1.08 \mathrm{Mg} \mathrm{m}^{-3}$ (Figure 1C). From 1.08 $\mathrm{Mg} \mathrm{m}^{-3}$ onwards, ER decreased as Bd increased, however, this trend was less pronounced than when the relation was positive. EP was $83 \%$ when $\mathrm{Bd}$ was $0.88 \mathrm{Mg} \mathrm{m}^{-3}$, and $100 \%$ for all the other $\mathrm{Bd}$ values, which indicates that it was less sensitive to Bd increase than ER (Figure 1D). Possibly, EP values represent the final values of emerged plants, while for ER calculation, the daily emergence values are considered. Around 72 and $76 \%$ variability in ER and EP, respectively, were explained by bulk density.

The regression model, when adjusted to the boundary points of ER response to the aggregate stability, indicated that ER was maximized up to values of around $30 \mathrm{~mL} \mathrm{m^{-1 }}$ (Figure 1E). However, the model was strongly affected by minor changes in aggregate stability above the optimum value. The value up to where EP was positively correlated was similar to that of the ER value (Figure 1F). Nevertheless, the increase in aggregate stability caused an abrupt decline that affected EP more than ER. The relation between EP and aggregate stability (0.91) had the highest determination coefficient value.

Both ER and EP were positively correlated with tensile strengths up to values of 95 and $87 \mathrm{kPa}$, respectively (Figures $2 \mathrm{~A}$ and $\mathrm{B})$. Therefore, these values represent the maxima that maize seedlings face without compromising development. From these values, there was a strong decline in emergence variables as tensile strength increased. The influence of tensile strength on ER and EP was similar, representing around 59 and 62\%, respectively, although EP was more sensitive than ER.

ER was strongly related with friability values from $0.13-0.50$ (Figure 2C), which indicates a positive influence from the slightly friable class $(0.1-0.2)$ up to the friable class (0.2-0.5). From the very friable class $(0.5-0.8)$, ER started a slow decline. Friability represents the tendency of a soil mass to dismantle in smaller aggregates because of a stress or load application, so it is of utmost importance for crop emergence. However, high friability values indicate that larger aggregates show a minor resistance to rupture compared to smaller ones (Seben Júnior et al., 2016), which explains the decrease in emergence parameters for the very friable class. Friability accounted for around $72 \%$ of ER variability. There was no significant relationship between EP and friability (data not shown).

The hydraulic conductivity value of saturated soil (log Ksat) of 1.40 seemed to be the optimum value for ER (Figure 2D). EP presented an optimum log Ksat of 1.46 and a less abrupt decrease as $\log$ Ksat increased (Figure 2E). There was a stronger relationship between ER and $\log$ Ksat, with $86 \%$ of the variability explained by that variable, while EP had $68 \%$ variability ascribed to $\log$ Ksat.

The ER showed more significant relations with the soil properties than EP, indicating that, for maize, such crop parameters present a better response to soil physical properties. 
A.

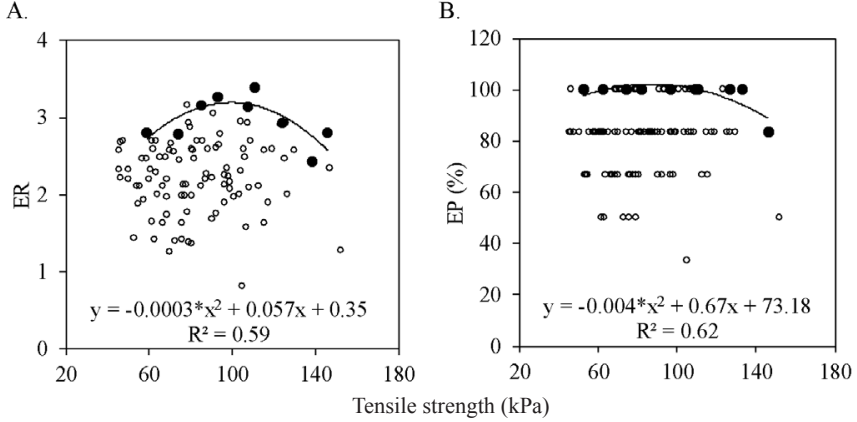

C.

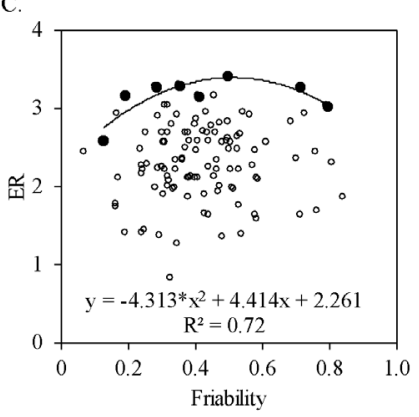

D.
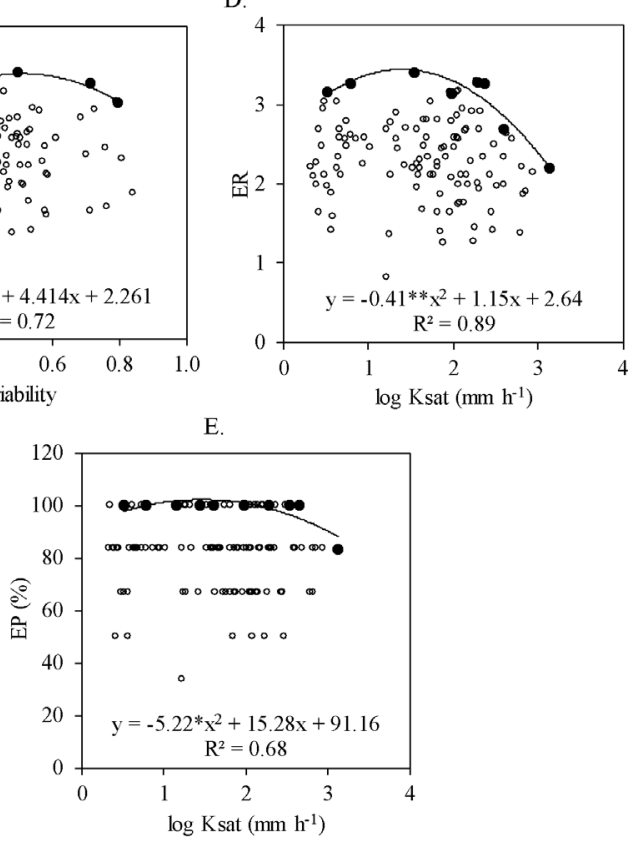

*, ** Significative at 0.05 and 0.01 , respectively, by $\mathrm{F}$ test

Figure 2. Dispersion and regression graphs from the boundary line approach for the maize plant emergence [emergence rate (ER) and emergence percentage (EP)] and soil seedbed physical properties [(A) and (B) - tensile strength; (C) - friability; (D) and (E) - hydraulic conductivity of saturated soil (log Ksat)]

The daily measurements used for ER calculation may be a possible reason for such results.

The selection of boundary points was also made for the soil parameter least limiting water range (LLWR); however, it did not present a significant adjustment for the regression model for the maize emergence parameters (EP and ER) (data not shown).

Relations among parameters of plant emergence and soil seedbed physical properties were all adjusted to a quadratic polynomial regression model (Figure 3). Correlations obtained for the soybean seedbed were different from those found for maize. Contrary to what happened for maize, EP was significantly correlated with penetration resistance and $\theta$ measured in the field. For Bd, which had a significant correlation with the maize seedbed, there was no correlation with soybean plant emergence.

Walworth et al. (1986) stated that such differences in regression models might happen among years because some factors and interactions have a year effect. Another issue concerns such differences among properties that had a negative correlation during one growth period and a positive correlation during another, or some other change, such as happened to the penetration resistance and $\theta$, which showed a linear correlation
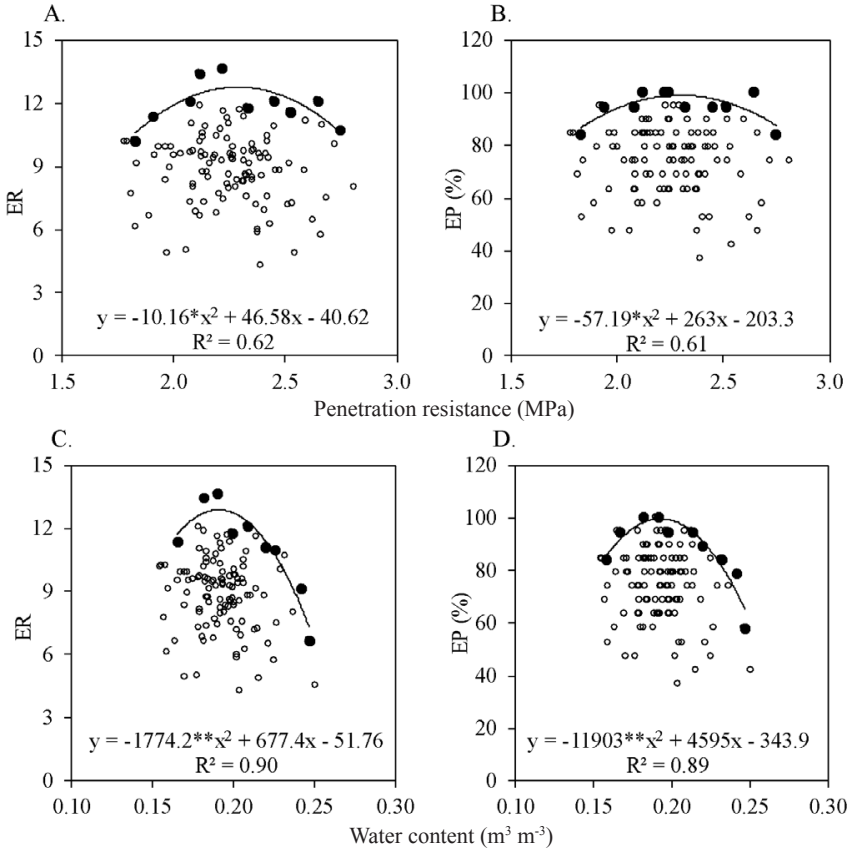

${ }^{*},{ }^{* *}$ Significative at 0.05 and 0.01 , respectively, by $\mathrm{F}$ test

Figure 3. Dispersion and regression graphs from the boundary line approach among soybean plant emergence [emergence rate (ER) and emergence percentage (EP)] and soil seedbed physical properties [(A) and (B) - penetration resistance; (C) and (D) volumetric water content $(\theta)]$

for the maize seedbed and a quadratic polynomial one for the soybean seedbed. This indicates that the evaluated physical properties were very dynamic temporally, promoting diverse crop responses from one year to another.

The penetration resistances measured in the soybean fields had very high values compared to those of the maize seedbed. However, both ER and EP were positively correlated with penetration resistances up to $2.29 \mathrm{MPa}$ (Figures $3 \mathrm{~A}$ and $\mathrm{B}$ ). Although expected, there was no abrupt decrease from this value; this indicates that, even with predominant penetration resistance values higher than $2 \mathrm{MPa}$, both ER and EP maintained appropriate values. Nevertheless, Lima et al. (2010) observed that penetration resistance above $1.9 \mathrm{MPa}$ negatively affected soybean plant height. Beutler et al. (2008) found results similar to this study, with soybean yield showing a polynomial relationship with penetration resistance, starting to decrease from penetration resistance values of $2.35 \mathrm{MPa}$. Even though penetration resistance accounted for around $60 \%$ of ER and EP variability, these results demonstrate that it was not the main limiting factor to soybean emergence. Bengough et al. (2006) reported that penetration resistance might not be the best indicator of plant growth hindrance, especially under a no-tillage system, where a net of continuous pores for root growth may be developed in a relatively dense soil matrix in such a way that roots can penetrate and colonize the compacted layers.

The $\theta$ measured in the soybean fields showed lower values than for maize. Both ER and EP were positively correlated with $\theta$ only up to $0.20 \mathrm{~m}^{3} \mathrm{~m}^{-3}$, as higher values promoted a strong decrease in ER and EP (Figures 3C and D). Both plant emergence parameters had around $90 \%$ variability explained by $\theta$. These results indicate that $\theta$ was more limiting for ER and EP than penetration resistance was. 
As with maize, soybean ER had a major response up to a tensile strength of $96 \mathrm{kPa}$ (Figure 4A). Above this value, ER slowly decreased as tensile strength increased. There was no significant relation between EP and tensile strength (data not shown). Both ER and EP showed a greater response to friability values of up to 0.27 (Figures $4 \mathrm{~B}$ and C). As in maize, friability positively influenced soybean emergence parameters up to the friable soil class. Such strong correlation indicated that friability was responsible for 71 and $85 \%$ of variation in ER and $\mathrm{EP}$, respectively.

EP was positively correlated with $\log$ Ksat up to $2.6 \mathrm{~mm} \mathrm{~h}^{-1}$, a value much superior to that found for maize (Figure $4 \mathrm{D}$ ). It is worth noting that, for maize, Ksat was determined in the laboratory, while for soybean, it was measured in the field. When log Ksat increased from $2.6 \mathrm{~mm} \mathrm{~h}^{-1}$, there was a slight EP decrease, which had 53\% variability accounted for Ksat. There was no significant correlation between ER and log Ksat (data not shown).

The LLWR optimum value for soybean ER was $0.16 \mathrm{~m}^{3} \mathrm{~m}^{-3}$ (Figure 4E). However, major plant responses occurred with this value; there was a strong ER decrease as LLWR increased. The
A.

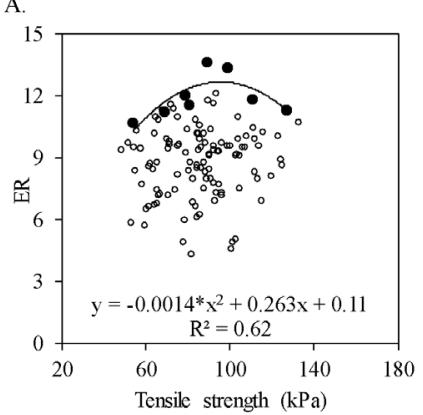

C.

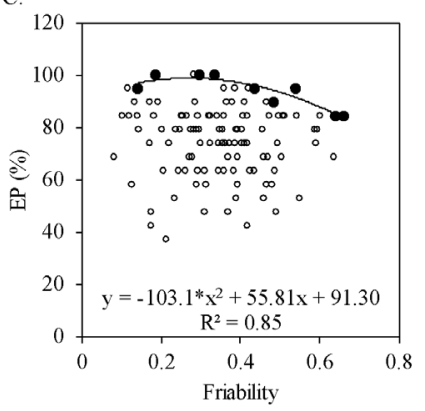

E.

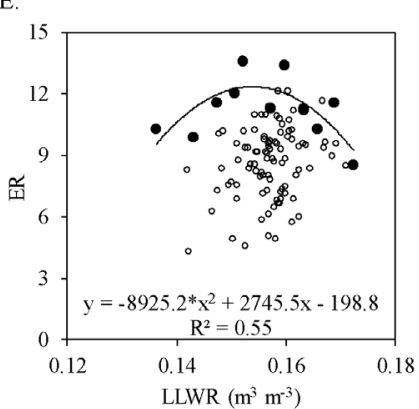

B.

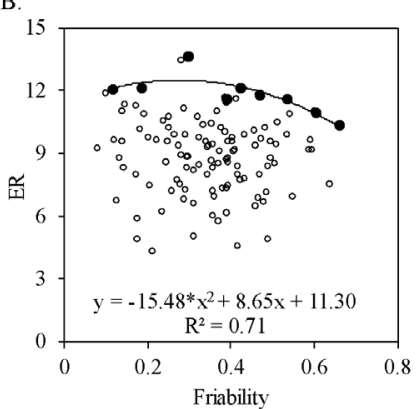

D.

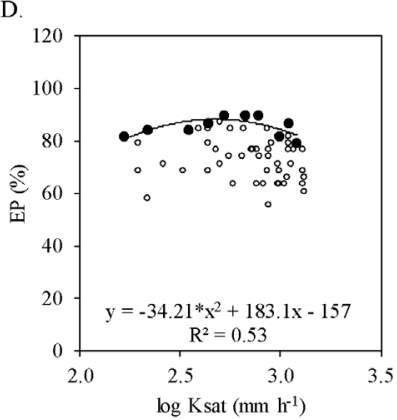

F.

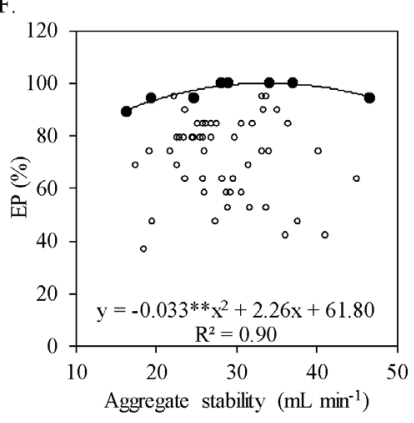

*, ** Significative at 0.05 and 0.01 , respectively, by F test

Figure 4. Dispersion and regression graphs from the boundary line approach among soybean plant emergence [emergence rate (ER) and emergence percentage (EP)] and soil seedbed physical properties [(A) - tensile strength; (B) and (C) - friability; (D) - hydraulic conductivity of saturated soil (log Ksat); (E) - least limiting water range (LLWR); (F) - aggregate stability]
LLWR theoretical basis suggests that the higher the LLWR, the more favorable the conditions are for plant development (Klein \& Klein, 2015). However, these results show that, for soybean $\mathrm{ER}$, there is an upper limit for which an LLWR increase favors crop development. The selected boundary points between EP and LLWR were not significantly correlated (data not shown).

The aggregate stability had an optimum value of $34.24 \mathrm{~mL} \mathrm{~min}^{-1}$ for EP (Figure 4F). Higher values presented a slight decrease, indicating that an increase in this soil attribute did not strongly affect plant emergence, even while explaining $90 \%$ of EP variation. This optimum value for aggregate stability falls in a rapid percolation rate, which denotes high aggregate stability. Mohanty et al. (2007) also obtained a positive linear correlation between aggregate stability and wheat yield; however, that was with a low determination coefficient $(0.28)$. There was no significant correlation between aggregate stability and ER (data not shown).

Relations among plant emergence variables and soil physical properties for both maize and soybean seedbeds indicate that both ER and EP presented high numbers even for values of soil physical properties above critical limits, especially of penetration resistance, bulk density, tensile strength, and friability. It is possible that emergence variables were more dependent on seed characteristics than on soil physical properties. However, these results were promising for the application of the boundary line approach, because such analysis may be a complementary tool to help to understand crop emergence responses to soil physical properties.

\section{Conclusions}

1. The application of boundary line approach showed that maize and soybean crop emergence is dependent on soil seedbed physical properties.

2. The relationships observed among plant emergence variables and soil physical properties allowed to know the optimum values for soil physical properties influencing the emergence variables of maize and soybean crops.

3. The boundary line approach is a promising tool to better understand crop emergence responses to soil seedbed physical properties.

\section{ACKNOWLeDgments}

We thank the Fundação de Pesquisa de São Paulo (FAPESP, Brazil) for granting a doctorate scholarship (Process number 2009/12106-2) to the first author; and Universidade Estadual de Ponta Grossa (UEPG) for allowing access to the experimental plots for this research.

\section{Literature Cited}

Atkinson, B. S.; Sparkes, D. L.; Mooney, S. J. Using selected soil physical properties of seedbeds to predict crop establishment. Soil \& Tillage Research, v.97, p.218-228, 2007. https://doi.org/10.1016/j. still.2007.09.017

Bengough, A. G.; Bransby, M. F.; Hans, J.; McKenna, S. J.; Roberts, T. J.; Valentine, T. A. Root responses to soil physical conditions: Growth dynamics from field to cell. Journal of Experimental Botany, v.57, p.437-443, 2006. https://doi.org/10.1093/jxb/erj003 
Beutler, A. N.; Centurion, J. F.; Silva, A. P. da; Centurion, M. A. P. da C.; Leonel, C. L.; Freddi, O. da S. Soil compaction by machine traffic and least limiting water range related to soybean yield. Pesquisa Agropecuária Brasileira, v.43, p.1591-1600, 2008. https://doi. org/10.1590/S0100-204X2008001100019

Blanco-Macías, F.; Magallanes-Quintanar, R.; Valdez-Cepeda, R. D.; Vázquez-Alvarado, R.; Olivares-Sáenz, E.; Gutiérrez-Ornelas, E.; Vidales-Contreras, J. A.; Murillo-Amador, B. Nutritional reference values for Opuntia ficus-indica determined by means of the boundary-line approach. Journal of Plant Nutrition and Soil Science, v.173, p.927-934, 2010. https://doi.org/10.1002/jpln.200900147

Casanova, D.; Goudriaan, J.; Bourna, J.; Eperna, G. F. Yield gap analysis in relation to soil properties in direct-seeded flooded rice. Geoderma, v.91, p.191-216, 1999. https://doi.org/10.1016/S00167061(99)00005-1

Casanova, D.; Goudriaan, J.; Forner, M. M. C.; Withagen, J. C. M. Rice yield prediction from yield components and limiting factors. European Journal of Agronomy, v.17, p.41-61, 2002. https://doi. org/10.1016/S1161-0301(01)00137-X

EMBRAPA - Empresa Brasileira de Pesquisa Agropecuária. Sistema brasileiro de classificação de solos. 2.ed. Rio de Janeiro: Embrapa Solos, 2013. 306p.

Guedes Filho, O. Qualidade física da cama de semeadura do solo em sistemas de manejo. Piracicaba: ESALQ/USP, 2012. 155p. Tese Doutorado. https://doi.org/10.11606/T.11.2012.tde-04012013160522

Guedes Filho, O.; Silva, A. P. da; Giarola, N. F. B.; Tormena, C. A. Structural properties of the soil seedbed submitted to mechanical and biological chiseling under no-tillage. Geoderma, v.204-205, p.94-101, 2013. https://doi.org/10.1016/j.geoderma.2013.04.017

Håkansson, I.; Myrbeck, A.; Etana, A. A review of research on seedbed preparation for small grains in Sweden. Soil \& Tillage Research, v.64, p.23-40, 2002. https://doi.org/10.1016/S0167-1987(01)00255-0

Imhoff, S.; Kay, B. D.; Silva, A. P. da; Hajabbasi, M. A. Evaluating responses of maize (Zea mays L.) to soil physical conditions using a boundary line approach. Soil \& Tillage Research, v.106, p.303-310, 2010. https://doi.org/10.1016/j.still.2009.11.007

Klein, C.; Klein, V. A. Least limiting water range under no-tillage system and maize grain yield. Revista Científica, v.43, p.179-187, 2015.

Lewandowski, I.; Schmidt, U. Nitrogen, energy and land use efficiencies of miscanthus, reed canary grass and triticale as determined by the boundary line approach. Agriculture, Ecosystems \& Environment, v.112, p.335-346, 2006. https://doi.org/10.1016/j.agee.2005.08.003

Lima, C. L. R. de; Reinert, D. J.; Reichert, J. M.; Suzuki, L. E. A. S. Produtividade de culturas e resistência à penetração de Argissolo Vermelho sob diferentes manejos. Pesquisa Agropecuária Brasileira, v.45, p.89-98, 2010. https://doi.org/10.1590/S0100204X2010000100012
Maguire, J. D. Speed of germination-aid in selection and evaluation for seedling emergence and vigor. Crop Science, v.2, p.176-177, 1962. https://doi.org/10.2135/cropsci1962.0011183X000200020033x

Maia, C. E.; Morais, E. R. C. de. Boundary line model to estimate the nutrient sufficiency range in muskmelon leaves. Revista Brasileira de Ciência do Solo, v.40, p.33-40, 2016. https://doi. org/10.1590/18069657rbcs20160033

Matula, J. Relationship between phosphorus concentration in soil solution and phosphorus in shoots of barley. Plant and Soil Environment, v.57, p.307-314, 2011. https://doi.org/10.17221/149/2011-PSE

Mohanty, M.; Painuli, D. K.; Misra, A. K.; Ghosh, P. K. Soil quality effects of tillage and residue under rice-wheat cropping on a Vertisol in India. Soil \& Tillage Research, v.92, p.243-250, 2007. https://doi. org/10.1016/j.still.2006.03.005

Otto, R.; Silva, A. P.; Franco, H. C. J.; Oliveira, E. C. A.; Trivelin, P. C. O. High soil penetration resistance reduces sugarcane root system development. Soil \& Tillage Research, v.117, p.201-210, 2011. https://doi.org/10.1016/j.still.2011.10.005

SAS Institute. Stastistical analysis system. SAS: User's guide statistics. 9.ed. Cary: SAS Institute, 2002. 943p.

Seben Júnior, G. de F.; Corá, J. E.; Lal, R. Physical quality of an Oxisol under no-tillage subjected to different cropping systems. Pesquisa Agropecuária Brasileira, v.51, p.1568-1574, 2016. https://doi. org/10.1590/s0100-204x2016000900056

Silva, A. P. da; Imhoff, S.; Kay, B. Plant response to mechanical resistance and air-filled porosity of soils under conventional and no-tillage system. Scientia Agricola, v.61, p.451-456, 2004. https://doi. org/10.1590/S0103-90162004000400016

Topp, C. F. E.; Wang, W.; Cloy, J. M.; Rees, R. M.; Hughes, G. Information properties of boundary line models for $\mathrm{N}_{2} \mathrm{O}$ emissions from agricultural soils. Entropy, v.15, p.972-987, 2013. https://doi. org/10.3390/e15030972

Vizcayno-Soto, G.; Côté, B. Boundary-line approach to determine standards of nutrition for mature trees from spatial variation of growth and foliar nutrient concentrations in natural environments. Communications in Soil Science and Plants Analysis, v.35, p.29652985, 2004. https://doi.org/10.1081/CSS-200036517

Walworth, J. L.; Letzsch, W. S.; Sumner, M. E. Use of boundary lines in establishing diagnostic norms. Soil Science Society of America Journal, v.50, p.123-128, 1986. https://doi.org/10.2136/ sssaj1986.03615995005000010024x

Weaich, K.; Cass, A.; Bristow, K. L. Use of a penetration resistance characteristic to predict soil strength development during drying. Soil \& Tillage Research, v.25, p.149-166, 1992. https://doi. org/10.1016/0167-1987(92)90108-N

Webb, R. A. Use of the boundary line in the analysis of biological data. Journal of Horticultural Science, v.47, p.309-319, 1972. https://doi. org/10.1080/00221589.1972.11514472 